Volume 6, No. 2, 2020

ISSN (print) : 2442-3217

ISSN (online) : 2716-3806

Homepage : http://journal.iaimsinjai.ac.id/indeks.php/mimbar

\title{
PENGARUH KECERDASAN EMOSIONAL TERHADAP PERILAKU MENYIMPANG REMAJA DI DESA SILAM \\ KECAMATAN KUOK KABUPATEN KAMPAR
}

\author{
Muhammad Ilyas ${ }^{1}$, Dea Nurul Azizah ${ }^{2}$ \\ ${ }^{1}$ Universitas Islam Negeri Sulthan Syarif Kasim, Pekanbaru, Riau \\ ${ }^{2}$ Universitas Islam Negeri Sulthan Syarif Kasim, Pekanbaru, Riau \\ E-mail: muhammad.ilyas@uin-suska.ac.id,Tlp:+6285365422655
}

\begin{abstract}
This study discusses emotional intelligence for adolescents in Silam Village, Kuok Subdistrict, Kampar District. The purpose of this study was to study how emotional intelligence on families in Silam Village, Kuok District, Kampar District. The type of research used is descriptive quantitative research. The population subjects were 250 teenagers in Silam Village and a sample of 71 adolescent Cluster Random Sampling. The technique of collecting data using a questionnaire with a Likert scale. The data analysis technique in this study was carried out by simple linear regression analysis, and the processing in this study used the SPSS version 17.0 (Statistical Products and Services Solution) program for windows. The results showed a significant influence between emotional intelligence on adolescent behavior in the Silam Village, Kuok Subdistrict, Kampar District. Based on the hypothesis test (Significant Test), the Probability value of $\alpha$ is $0.05 \mathrm{ig}$ sig $(0.05 \geq 0.00)$ which means $\mathrm{Ha}$ is accepted and Ho is rejected. Thus it can be denied that emotional intelligence is approved of adolescent behavior.
\end{abstract}

Keywords: Emotional Intelligence, Youth Behavior, Teenager 


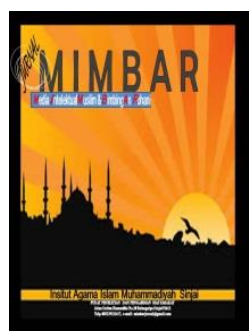

\section{MIMBAR}

Jurmal Media Intelektual Muslim dan Bimbingan Rohani

Volume 6, No. 2, 2020

ISSN (print) : 2442-3217

ISSN (online) : 2716-3806

Homepage : http://journal.iaimsinjai.ac.id/indeks.php/mimbar

\section{Pendahuluan}

Kehidupan remaja merupakan bagian yang sangat banyak mengalami kesukaran dalam hidup manusia, dimana remaja masih memiliki kejiwaan atau emosi yang mudah berubah-ubah dan berusaha untuk menemukan jati diri.Tahap remaja melibatkan suatu proses yang menjangkau suatu periode penting dalam kehidupan sesorang. Selain itu, masa ini merupakan masa pencarian nilai-nilai hidup. Masa remaja adalah masa yang amat baik untuk mengembangkan segala potensi positif yang dimilikinya seperti bakat, minat, dan kemampuan.

Masa remaja mengalami begitu banyak tantangan, karena banyaknya perubahan fisik, biologis, psikologis, dan juga sosial. Proses-proses perubahan penting akan terjadi dalam diri remaja jika perubahan-perubahan ini mampu dihadapi secara adaptif dan sukses. Ketika seorang remaja tidak mampu berhadapan dan mengatasi tantangan perubahan ini secara sukses, akan muncul berbagai konsekuensi psikologis, emosional, dan behavioral yang merugikan berbentuk perilaku yang menyimpang.

Menurut para ahli psikologi, kenakalan remaja biasanya dilakukan oleh remaja-remaja yang gagal dalam menjalani proses-proses perkembangan jiwanya, baik pada saat remaja maupun pada masa kanak-kanaknya.Secara psikologis, kenakalan remaja merupakan wujud dari konflik-konflik yang tidak terselesaikan dengan baik. Seringkali didapati remaja yang berperilaku menyimpang tersebut mengalami trauma dalam masa lalunya, baik trauma secara fisiologis maupuntrauma psikologis berupa perlakuan kasar atau tidak menyenangkan dari teman-teman dan lingkungannya, dan trauma terhadap kondisi lingkungannya.

Kondisi pada saat ini, orang tua dalam mendidik remaja dengan baik mendapatkan tantangan yang sangat berat, bagaimana upaya untuk melindungi remaja dari pengaruh-pengaruh buruk dilingkungannya yang dapat merusak masa depan mereka. Remaja merupakan penerus bangsa, di tangan remajalah masa depan bangsa ini digantungkan. Oleh karena itu semua permasalahan tersebut perlu 


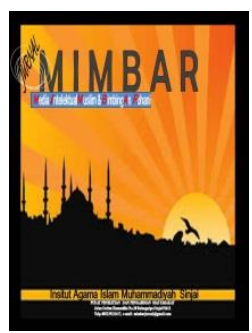

\section{MIMBAR}

Jurnal Media Intelektual Muslim dan Bimbingan Rohani

Volume 6, No. 2, 2020

ISSN (print) : 2442-3217

ISSN (online) : 2716-3806

Homepage : http://journal.iaimsinjai.ac.id/indeks.php/mimbar

mendapat perhatian dari berbagai pihak agar mengurangi permasalahan kenakalan remaja.

Syamsu mengatakan bahwa ternyata tidak semua remaja mampu menampilkan secara wajar dan sehat (well adjustment) dalam upaya memenuhi kebutuhan atau memecahkan masalah yang dihadapinya. Diantaranya mereka banyak juga yang mengalami tidak sehat (maladjustment). Remaja muda yang kurang percaya diri pada status mereka dalam suatu kelompok tertentu, cenderung menyesuaikan diri secara berlebihan, bila hal ini diteruskan sampai akhir masa dewasanya, maka hal ini menandakan ketidak matangan. ${ }^{1}$

Hurlock mengatakan tanda-tanda ketidakmatangan yang lain dibidang perilaku sosial adalah diskriminatif terhadap mereka yang berlatar belakang ras, agama atau sosial ekonomi yang berbeda. Dalam usahanya untuk menarik perhatian orang lain remaja sering menghina orang lain yang berbeda latar belakang, membual, menertawakan orang lain,sombong, menggunakan bahasa yang tidak lazim, dan mengenakan pakaian yang mencolok. ${ }^{2}$

Milner dalam Penney Upton mengemukakan bahwa remaja menganggap untuk memperoleh rasa penerimaan dan memiliki dengan kelompok sebaya mereka menggunakan sesuatu yang unik atau melakukan sesuatu yang berbeda dari yang lainnya. Jika tidak melakukan hal-hal tersebut, remaja merasa kehilangan jati diri dan mendapat ejekan dari teman-temannya. ${ }^{3}$ Apabila seorang tidak diterima pada kelompok sebayanya, remaja cenderung tidak percaya diri dan benci pada dirinya sendiri, cenderung tidak dapat menyesuaikan diri, merasa tidak bahagia dan merasa di kucilkan. Akibatnya, ia tidak mengalami saat-saat menggembirakan seperti yang dirasakan teman-teman sebayanya dan merasa tidak memperoleh perhatian dari keluarganya. Sebagian besar remaja yang penyesuaian dirinya buruk merasa lebih tidak bahagia.

\footnotetext{
1 Syamsu Yusuf. Psikologi Perkembangan, Anak dan Remaja. (Bandung: Rosda Karya,

${ }^{2}$ E. Hurlock, Psikologi Perkembangan. (Jakarta: Erlangga, 2006), hal. 238.

${ }^{3}$ Penney Upton, Psikologi Perkembangan. (Jakarta: Erlangga, 2012), hal. 207.
} 


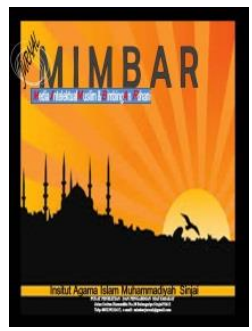

\section{MIMBAR}

Jurnal Media Intelektual Muslim dan Bimbingan Rohani

Volume 6, No. 2, 2020

ISSN (print) : 2442-3217

ISSN (online) : 2716-3806

Homepage : http://journal.iaimsinjai.ac.id/indeks.php/mimbar

Remaja yang tidak bisa menyesuaikan diri dengan lingkungannya biasanya akan menarik diri dari lingkungannya. Penarikan diri seperti itu oleh Merton dalam Sarlito dikatakan sebagai salah satu reaksi dari keadaan anomie, yaitu, remaja merasakan seakan-akan keadaan lingkungan disekitarnya tidak ada lagi yang menjadi patokan atau tolak ukur yang pasti bagi mereka untuk menyatakan perilaku mana yang benar dan perilaku mana yang salah. Hal ini menyebabkan kebingungan pada remaja yang keadaan kepribadiannya masih penuh gejolak dan goncangan. ${ }^{4}$

Remaja dalam masa mencari identitas diri seringkali memiliki emosi yang menggebu. Emosi tak terkendali itu antara lain disebabkan juga oleh konflik peran yang dialami remaja. Ia masih tergantung pada orang tua, namun ia ingin bebas, ia masih diperlakukan sebagai anak kecil, sementara ia merasa sudah dewasa. Dengan adanya emosi-emosi itu, secara bertahap remaja akan mencari jalannya sendiri dalam menuju kedewasaan. Remaja dapat mengambil pelajaran melalui reaksi emosi orangorang disekitarnya dalam mengambil langkah yang terbaik untuk kedepannya.

Pada masa remaja, individu mengalami perkembangan yang pesat mencapai kematangan fisik, sosial, dan emosi.Perkembangan emosi pada aspek ini meliputi kemapuan remaja untuk mencintai, merasa nyaman, berani, gembira, takut, dan marah serta bentuk-bentuk emosi lainnya. Periode ini disebut sebagai periode heightened emotionality, yaitu suatu keadaan dimana kondisi emosi tampak lebih tinggi atau tampak lebih intens dibandingkan dengan keadaan normal. Emosi yang tinggi dapat termanifestasikan dalam berbagai bentuk perilaku seperti bingung, emosi berkobar-kobar atau mudah meledak, bertengkar, tak bergairah, pemalas, membentuk mekanisme pertahanan diri. ${ }^{5}$

Permasalahannya adalah jika seorang tidak berhasil mengatasi situasi-situasi kritis dalam konflik peran dan remaja terlalu mengikuti gejolak emosi, maka besar kemungkinan akan melakukan perilaku-perilaku yang menyimpang. Oleh karena itu

\footnotetext{
${ }^{4}$ Sarlito W. Sarwono, Psikologi Remaja, (Jakarta: Rajawali Pers, 2016), hal. 262.

5 Alma Yulianti, Psikologi Perkembangan, Sepanjang Rentang Kehidupan, (Pekanbaru: AlMujtahadah Press, 2013), hal. 111.
} 


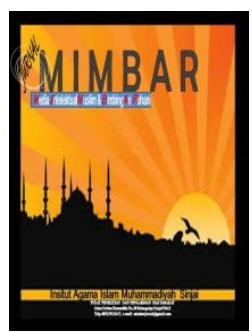

\section{MIMBAR}

Jurnal Media Intelektual Muslim dan Bimbingan Rohani

Volume 6, No. 2, 2020

ISSN (print) : 2442-3217

ISSN (online) : 2716-3806

Homepage : http://journal.iaimsinjai.ac.id/indeks.php/mimbar

remaja perlu memiliki kecerdasan emosional yang baik agar mampu mengendalikan perilakunya di lingkungannya. Manusia yang seutuhnya harus dapat menyatukan tiga potensi dasar, yaitu manusia yang tidak saja memiliki kecerdasan intelektual dan kecerdasan spiritual namun juga memiliki kecerdasan emosional.

Penulis mengamati banyak dari remaja-remaja yang ada di desa Silam yang melakukan perilaku-perilaku yang menyimpang seperti mencuri, pacaran, konsumsi lem, kebut-kebutan di jalan dan perilaku menyimpang lainnya yang meresahkan masyarakat. Berdasarkan wawancara prapenelitian yang dilakukan pada Ketua Pemuda Desa Silam, remaja di desa Silam secara umum perilakunya sudah baik, hanya saja sebagian banyak yang melakukan perilaku menyimpang seperti kebutkebutan di jalan, konsumsi lem, pacaran, mencuri dan sebagainya. Akan tetapi yang sering terjadi dari semua permasalahan tersebut yaitu mencuri. Dan untuk penyelesaiannya di selesaikan secara musyawarah antar keluarga. ${ }^{6}$

Masalah perilaku menyimpang remaja memerlukan perhatian kaum pendidik secara sungguh-sungguh agar teratasi dengan baik. Mengatasi kenakalan remaja yaitu dengan cara menata kembali emosinya. Menata kembali emosi dan perasaan remaja yang rusak karena sejak kecil merasa ditolak oleh keluarganya, orang tua, temanteman, dan lingkungannya, dan gagalnya proses perkembangan jiwa remaja tersebut. Dengan menempatkan anak di lingkungan yang baik dan memiliki pemahaman yang baik tentang perkembangan anak serta meningkatkan kecerdasan emosional anak tersebut akan banyak membantu mengurangi kenakalan remaja.

\section{Metode}

Jenis penelitian dan data dalam penelitian ini dengan menggunakan metode kuantitatif berupa angka-angka dan analisis menggunakan statistik. ${ }^{7}$ Penelitian kuantitatif sebagai metode penelitian yang berlandaskan pada filsafat positivisme,

\footnotetext{
${ }^{6}$ Amtiru Fajri, Ketua Pemuda Desa Silam Kecamatan Kuok Kabupaten Kampar, Wawancara personal, 14 Juli 2018.

${ }^{7}$ Sugiyono, Metode Penelitian Kuantitatif, Kualitatif dan R \& D, (Bandung: Alfabeta, 2013), hal. 7.
} 


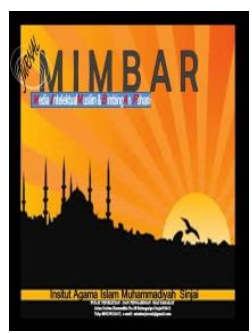

\section{MIMBAR}

Jurnal Media Intelektual Muslim dan Bimbingan Rohani

Volume 6, No. 2, 2020

ISSN (print) : 2442-3217

ISSN (online) : 2716-3806

Homepage : http://journal.iaimsinjai.ac.id/indeks.php/mimbar

digunakan untuk meneliti pada populasi atau sampel tertentu. ${ }^{8}$ Penelitian ini menggunakan pendekatan "Descriptive Research" atau penelitian deskriptif yaitu penelitian yang menggambarkan sifat-sifat atau karakter individu, keadaan, gejala atau kelompok tertentu. Penulis mengambil loakasi penelitian di Desa Silam kecamatan Kuok Kabupaten Kampar, Provinsi Riau. Lokasi ini dipilih terkait pertimbangan aksebilitas dan kesesuaian fenomena yang ditemui di lapangan dengan studi yang menjadi pokok bahasan bagi penulis. Objek dalam penelitian ini adalah pengaruh kecerdasan emosional terhadap perilaku remaja. Adapun yang menjadi subjek penelitian ini adalah remaja masa pertengahan dan masa remaja masa akhir yaitu remaja yang berusia 15 sampai 21 tahun di desa Silam kecamatan Kuok kabupaten Kampar.

Dalam penelitian pengaruh kecerdasan emosional terhadap perilaku remaja di desa Silam yang menjadi populasi adalah seluruh remaja yang dalam masa pertengahan dan remaja masa akhir yaitu remaja yang berusia 15 sampai 21 tahun di desa Silam yang berjumlah 250 orang. ${ }^{9}$

Pada penelitian ini, penulis menggunakan rumus Slovin untuk mengetahui jumlah sampel. Yaitu :

$$
\mathrm{n}=\frac{\mathrm{N}}{1+\left(\mathrm{N} \times \mathrm{e}^{2}\right)}
$$

\section{Keterangan:}

n : Jumlah Sampel

$\mathrm{N}$ : Jumlah Populasi

e : Error Level (Tingkat Kesalahan 0,1; 0,05; dan 0,001) ${ }^{10}$

Berdasarkan rumus tersebut diperoleh jumlah sampel sebagai berikut:

$$
\mathrm{n}=\frac{\mathrm{N}}{1+\left(\mathrm{N} \times \mathrm{e}^{2}\right)}
$$

\footnotetext{
${ }^{8}$ Dewi Sadiah, Metode Penelitian Dakwah, Pendekatan Kualitatif dan Kuantitatif. (Bandung: Remaja Rosdakarya, 2015), hal. 16.

${ }^{9}$ Data Kantor Desa Silam Kecamatan Kuok Kabupaten Kampar tahun 2018

${ }^{10}$ Riduwan, Skala Pengukuran Variabel-Variabel Penelitian, (Bandung: Alfabeta, 2013), hal. 12.
} 


$$
\begin{gathered}
\mathrm{n}=\frac{250}{1+\left(250 \times\left(0,1^{2}\right)\right)} \\
\mathrm{n}=\frac{250}{1+(250 \times 0,01)} \\
\mathrm{n}=\frac{250}{1+2,5} \\
\mathrm{n}=\frac{250}{3,5}=71,4 \\
\mathrm{n}=71
\end{gathered}
$$

jumlah sampel pada penelitian ini yaitu 71 responden atau $28,4 \%$ dari jumlah populasi.

Untuk menguji validitas penulis menilik isi dan kegunaan kebenaran alat ukur apakah sudah akurat atau belum, atau apakah alat ukur telah sesuai dengan variabel dan indikator yang ada dan disesuaikan pula dengan teori ataupun hasil pengkajian terdahulu. Metode yang dipakai untuk mengukur validitas instrument penelitian ini adalah "Construct Validity". 11

Dalam penelitian ini untuk menguji ketepatan atau kebenaran penelitian tersebut dipakai metode perhitungan indeks reliabilitas secara metode ulang atau "Test-Retest" dilakukan dengan cara mencobakan instrumen beberapa kali pada responden dan dipakai juga Reliability Statistic dengan menggunakan SPSS 17,0.

Dalam menganalisa data, penulis menggunakan teknik Analisis Regresi Linear. Analisis regresi linear digunakan untuk mengetahui bagaimana variabel dependent (terikat) dapat diprediksikan (meramalkan) melalui variabel independent (bebas) secara parsial ataupun secara bersama-sama (simultan). Analisis regresi linear dapat digunakan untuk kebijakan apakah ingin menaikkan atau menurunkan variabel independent. ${ }^{12} \mathrm{Pada}$ penelitian ini penulis menggunakan satu variabel independent dan satu variabel dependent, yaitu:

$$
\mathrm{X}=\text { Kecerdasan Emosional }
$$

\footnotetext{
${ }^{11}$ Sugiyono, Op. Cit., hal. 125.

${ }^{12}$ Riduwan, dkk, Cara Mudah Belajar SPSS 17.0 dan Aplikasi Statistik Penelitian, (Bandung: Alfabeta, 2013), Hal. 93.
} 
$\mathrm{Y}=$ Perilaku Remaja

Bentuk persamaan Regresi Sederhana sebagai berikut:

$\dot{Y}=\mathrm{a}+\mathrm{Bx}$

Keterangan:

$\hat{Y}=$ Nilai yang diprediksikan

$\mathrm{a}=$ Konstanta atau bila harga $\mathrm{X}=0$

$\mathrm{B}=$ Koefisien Regresi

$\mathrm{X}=$ Nilai Variabel Independen

\section{Hasil dan Pembahasan}

Untuk menguji validitas dalam penelitian ini, penulis menggunakan Statistical Product and Service Solution (SPSS) 17,0 dengan menggunakan analisis statistik. Untuk mengetahui tingkat validitas dilakukan uji signifikan dengan membandingkan nilai $r_{\text {hitung }}$ dengan $r_{\text {tabel }}$, dengan menghitung degre of freedom $(\mathrm{df})$. Untuk $\mathrm{df}=\mathrm{n}-2$, dalam hal ini $\mathrm{n}$ adalah jumlah sampel dan 2 adalah jumlah konstruk. Berdasarkan pada kasus ini besar df dapat dihitung 71-2 atau df-69 untuk signifikan 0,05 adalah 0,233 .

Pada korelasi item total digunakan batasan $r_{\text {hitung }} \geq r_{\text {tabel }}(0,233)$. Semua item yang mencapai koefisien korelasi minimal 0,233 daya pembedanya dianggap memuaskan, sedangkan item yang kurang dari 0,233 sianggap sebagai item yang memiliki daya pembeda rendah. Apabila setelah dilakukan seleksi item ditemukan bahwa item-item yang lolos belum mencukupi jumlah yang diinginkan atau kurang dapat mewakili aspek-aspek yang diukur maka dapat dipertimbangkan dengan merumuskan $r_{\text {hitung }} \geq r_{\text {tabel }}(0,233){ }^{13}$

Pada skala kecerdasan emosional dilakukan seleksi item dengan batasan $\mathbf{r}_{\text {hitung }}$ $\geq r_{\text {tabel }}(0,233)$. Item dianggap memenuhi kriteria atau dianggap valid apabila memilki korelasi item total $\geq 0,233$, sedangkan item yang memiliki korelasi item total $<0,233$

\footnotetext{
${ }^{13}$ Riduwan, dkk, Op. Cit., hal. 200.
} 


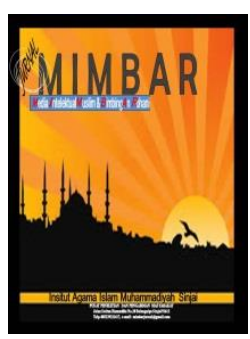

\section{MIMBAR}

Jurmal Media Intelektual Muslim dan Bimbingan Rohani

Volume 6, No. 2, 2020

ISSN (print) : 2442-3217

ISSN (online) : 2716-3806

Homepage : http://journal.iaimsinjai.ac.id/indeks.php/mimbar

dianggap tidak memenuhi kriteria atau tidak valid. Karena itu, item-item ini harus digugurkan. Setelah dilakukan uji coba dengan menggunakan terhadap skala penelitian. Jumlah item skala Kecerdasan Emosional yang sahih dari 30 item adalah 27 item dan item yang gugur berjumlah 3 item. Berikut ini tabel item yang valid dan yang gugur untuk skala kecerdasan emosional:

Tabel 1 Validitas Skala Kecerdasan Emosional

\begin{tabular}{|c|c|c|c|}
\hline ITEM n=71 & r hitung & $\begin{array}{c}\mathrm{r} \text { tabel }=0.233 \alpha=0,05 \\
d k=n-2\end{array}$ & Keputusan \\
\hline X.1 & 0.579 & 0.233 & Valid \\
\hline X.2 & 0.182 & 0.233 & Tidak Valid \\
\hline X.3 & 0.490 & 0.233 & Valid \\
\hline X.4 & 0.662 & 0.233 & Valid \\
\hline X.5 & 0.543 & 0.233 & Valid \\
\hline X.6 & 0.354 & 0.233 & Valid \\
\hline $\mathrm{X} .7$ & 0.407 & 0.233 & Valid \\
\hline X.8 & 0.520 & 0.233 & Valid \\
\hline X.9 & 0.641 & 0.233 & Valid \\
\hline X.10 & 0.325 & 0.233 & Valid \\
\hline X.11 & 0.103 & 0.233 & Tidak Valid \\
\hline X.12 & 0.618 & 0.233 & Valid \\
\hline $\mathrm{X} .13$ & 0.720 & 0.233 & Valid \\
\hline X.14 & 0.749 & 0.233 & Valid \\
\hline X.15 & 0.500 & 0.233 & Valid \\
\hline X.16 & 0.565 & 0.233 & Valid \\
\hline X.17 & 0.369 & 0.233 & Valid \\
\hline X.18 & 0.545 & 0.233 & Valid \\
\hline X.19 & 0.664 & 0.233 & Valid \\
\hline X.20 & 0.676 & 0.233 & Valid \\
\hline
\end{tabular}




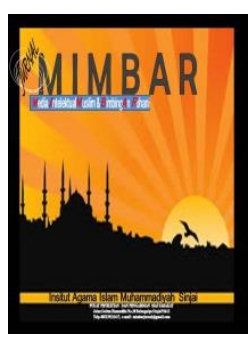

MIMBAR

Jurnal Media Intelektual Muslim dan Bimbingan Rohani

Volume 6, No. 2, 2020

ISSN (print) : 2442-3217

ISSN (online) : 2716-3806

Homepage : http://journal.iaimsinjai.ac.id/indeks.php/mimbar

\begin{tabular}{|l|c|c|c|}
\hline X.21 & 0.592 & 0.233 & Valid \\
\hline X.22 & 0.676 & 0.233 & Valid \\
\hline X.23 & 0.604 & 0.233 & Valid \\
\hline X.24 & 0.183 & 0.233 & Tidak Valid \\
\hline X.25 & 0.633 & 0.233 & Valid \\
\hline X.26 & 0.620 & 0.233 & Valid \\
\hline X.27 & 0.691 & 0.233 & Valid \\
\hline X.28 & 0.471 & 0.233 & Valid \\
\hline X.29 & 0.498 & 0.23 & Valid \\
\hline X.30 & 0.547 & 0.233 & Valid \\
\hline
\end{tabular}

Tabel 2 Skala Kecerdasan Emosional Setelah Dilakukan Uji Coba/Try Out

\begin{tabular}{|c|c|c|c|c|}
\hline \multirow{2}{*}{ No } & \multirow{2}{*}{ Indikator } & \multicolumn{2}{|c|}{ Nomor Item } & \multirow{2}{*}{ Jumlah } \\
\hline & & Valid & Tidak Valid & \\
\hline 1 & Pengenalan Diri & $1,3,4$ & 2 & 4 \\
\hline 2 & Pengendalian Diri & $\begin{array}{c}5,6,7,8,9 \\
10,12\end{array}$ & 11 & 8 \\
\hline 3 & Motivasi & $13,14,15,16$ & & 4 \\
\hline 4 & Empati & $\begin{array}{c}17,18,19,20, \\
21,22\end{array}$ & & 6 \\
\hline 5 & $\begin{array}{l}\text { Keterampilan } \\
\text { Sosial }\end{array}$ & $\begin{array}{c}23,25,26,27 \\
28,29,30\end{array}$ & 24 & 8 \\
\hline & Jumlah & 27 & 3 & 30 \\
\hline
\end{tabular}

Pada skala perilaku remaja dilakukan seleksi item dengan batasan $r_{\text {hitung }} \geq r_{\text {tabel }}$ $(0,233)$. Item dianggap memenuhi kriteria atau dianggap valid apabila memilki korelasi item total $\geq 0,233$, sedangkan item yang memiliki korelasi item total $<0,233$ dianggap tidak memenuhi kriteria atau tidak valid. Karena itu, item-item ini harus 


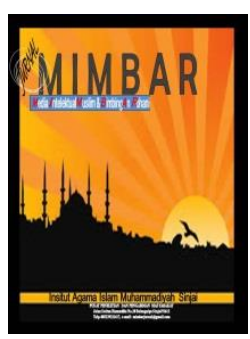

\section{MIMBAR}

Jurmal Media Intelektual Muslim dan Bimbingan Rohani

Volume 6, No. 2, 2020

ISSN (print) : 2442-3217

ISSN (online) : 2716-3806

Homepage : http://journal.iaimsinjai.ac.id/indeks.php/mimbar

digugurkan. Setelah dilakukan uji coba dengan menggunakan terhadap skala penelitian, jumlah item skala Perilaku Remaja yang sahih dari 22 item adalah 19 item dan item yang gugur berjumlah 3 item. Berikut ini tabel item yang valid dan yang gugur untuk skala perilaku remaja:

Tabel 3 Validitas Skala Perilaku Remaja

\begin{tabular}{|c|c|c|c|}
\hline ITEM n=71 & $r$ hitung & $\begin{array}{l}r \text { tabel }=0.233 \\
\alpha=0,05 ; d k=n-2\end{array}$ & Keputusan \\
\hline Y.1 & 0.579 & 0.233 & Valid \\
\hline Y.2 & 0.661 & 0.233 & Valid \\
\hline Y.3 & 0.598 & 0.233 & Valid \\
\hline Y.4 & 0.586 & 0.233 & Valid \\
\hline Y.5 & 0.573 & 0.233 & Valid \\
\hline Y.6 & 0.619 & 0.233 & Valid \\
\hline Y.7 & 0.614 & 0.233 & Valid \\
\hline Y.8 & 0.612 & 0.233 & Valid \\
\hline Y.9 & 0.659 & 0.233 & Valid \\
\hline Y.10 & 0.490 & 0.233 & Valid \\
\hline Y.11 & 0.191 & 0.233 & Tidak Valid \\
\hline Y.12 & 0.499 & 0.233 & Valid \\
\hline Y.13 & 0.731 & 0.23 & Valid \\
\hline Y.14 & 0.547 & 0.233 & Valid \\
\hline Y.15 & 0.676 & 0.233 & Valid \\
\hline Y.16 & 0.191 & 0.233 & Tidak Valid \\
\hline Y.17 & 0.200 & 0.233 & Tidak Valid \\
\hline Y.18 & 0.448 & 0.233 & Valid \\
\hline Y.19 & 0.543 & 0.233 & Valid \\
\hline Y.20 & 0.635 & 0.233 & Valid \\
\hline
\end{tabular}


Volume 6, No. 2, 2020

ISSN (print) : 2442-3217

ISSN (online) : 2716-3806

Homepage : http://journal.iaimsinjai.ac.id/indeks.php/mimbar

\begin{tabular}{|l|l|l|l|}
\hline Y.21 & 0.720 & 0.233 & Valid \\
\hline Y.22 & 0.718 & 0.233 & Valid \\
\hline
\end{tabular}

Tabel 4 Blue Print Skala Perilaku Remaja setelah dilakukan uji coba/try out

\begin{tabular}{|c|c|c|c|c|}
\hline \multirow[b]{2}{*}{ No } & \multirow[b]{2}{*}{ Indikator } & \multicolumn{2}{|c|}{ Nomor Item } & \multirow[b]{2}{*}{ Jumlah } \\
\hline & & Valid & $\begin{array}{l}\text { Tidak } \\
\text { Valid }\end{array}$ & \\
\hline 1 & $\begin{array}{l}\text { Kenakalan yang menimbulkan } \\
\text { korban fisik pada dan orang lain }\end{array}$ & $\begin{array}{c}1,2,3 \\
4,5\end{array}$ & & 5 \\
\hline 2 & $\begin{array}{l}\text { Kenakalan yang menimbulkan } \\
\text { korban materi }\end{array}$ & $\begin{array}{c}6,7,8 \\
9,10\end{array}$ & & 5 \\
\hline 3 & $\begin{array}{l}\text { Kenakalan sosial yang tidak } \\
\text { menimbulkan korban di pihak orang } \\
\text { lain }\end{array}$ & $\begin{array}{l}12,13 \\
14,15\end{array}$ & $\begin{array}{c}11,16 \\
17\end{array}$ & 7 \\
\hline 4 & Kenakalan yang melawan status & $\begin{array}{l}18,19, \\
20,21, \\
22\end{array}$ & & 5 \\
\hline & Jumlah & 19 & 3 & 22 \\
\hline
\end{tabular}

\section{Uji Reliabilitas}

Pengujian reliabilitas dapat dilakukan secara eksternal (stability/test retest, equivalent, atau gabungan keduanya dan secara internal (analisis konsistensi butir-butir yang ada pada instrumen. Dalam penelitian ini untuk menguji ketepatan atau kebenaran penelitian tersebut dipakai metode perhitungan indeks reliabilitas secara metode ulang atau "Test-Retest" dilakukan dengan cara mencobakan instrumen beberapa kali pada responden dan dipakai juga Alpha Cronbachdengan menggunakan SPSS 17,0. Kriteria 


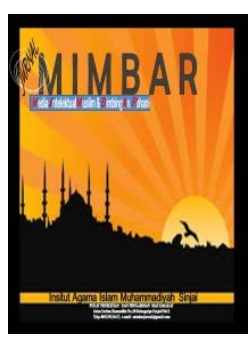

\section{MIMBAR}

Jurmal Media Intelektual Muslim dan Bimbingan Rohani

Volume 6, No. 2, 2020

ISSN (print) : 2442-3217

ISSN (online) : 2716-3806

Homepage : http://journal.iaimsinjai.ac.id/indeks.php/mimbar

suatu instrumen dikatakan reliabel dengan menggunakan teknik ini, bila koefisien reliabilitas $\geq 0,233$.

Tabel 5 Hasil Uji Reliabilitas

\begin{tabular}{|c|c|c|c|}
\hline Variabel & $\begin{array}{c}\text { Nilai Cronbach } \\
\text { Alpha }\end{array}$ & $\begin{array}{c}\text { Syarat Cronbach } \\
\text { Alpha }\end{array}$ & Keputusan \\
\hline Variabel (X) & 0,784 & 0,233 & Reliabel \\
Kecerdasan & & & \\
Emosinal & & 0,233 & Reliabel \\
\hline $\begin{array}{c}\text { Variabel (Y) } \\
\text { Perilaku } \\
\text { Remaja }\end{array}$ & 0,765 & & \\
\hline
\end{tabular}

Dari tabel diatas menunjukkan bahwa kedua variabel dinyatakan reliabel karena keduanya memiliki nilai Cronbach's Alpha lebih besar dari syarat Cronbach's Alpha. Adapun nilai Cronbach's Alpha untuk variabel kecerdasan emosional (variabel $\mathrm{X}$ ), yaitu $0,784 \geq 0,233$ yang merupakan nilai syarat Cronbach's Alpha sedangkan untuk variabel perilaku remaja (variabel Y) nilai Cronbach's Alpha 0,765 $\geq 0,233$. 
Volume 6, No. 2, 2020

ISSN (print) : 2442-3217

ISSN (online) : 2716-3806

Homepage : http://journal.iaimsinjai.ac.id/indeks.php/mimbar

\section{Uji Normalitas}

\section{Normal Probability}

\section{Normal P-P Plot of Regression Standardized Residual}

\section{Dependent Variable: Perilaku Remaja}

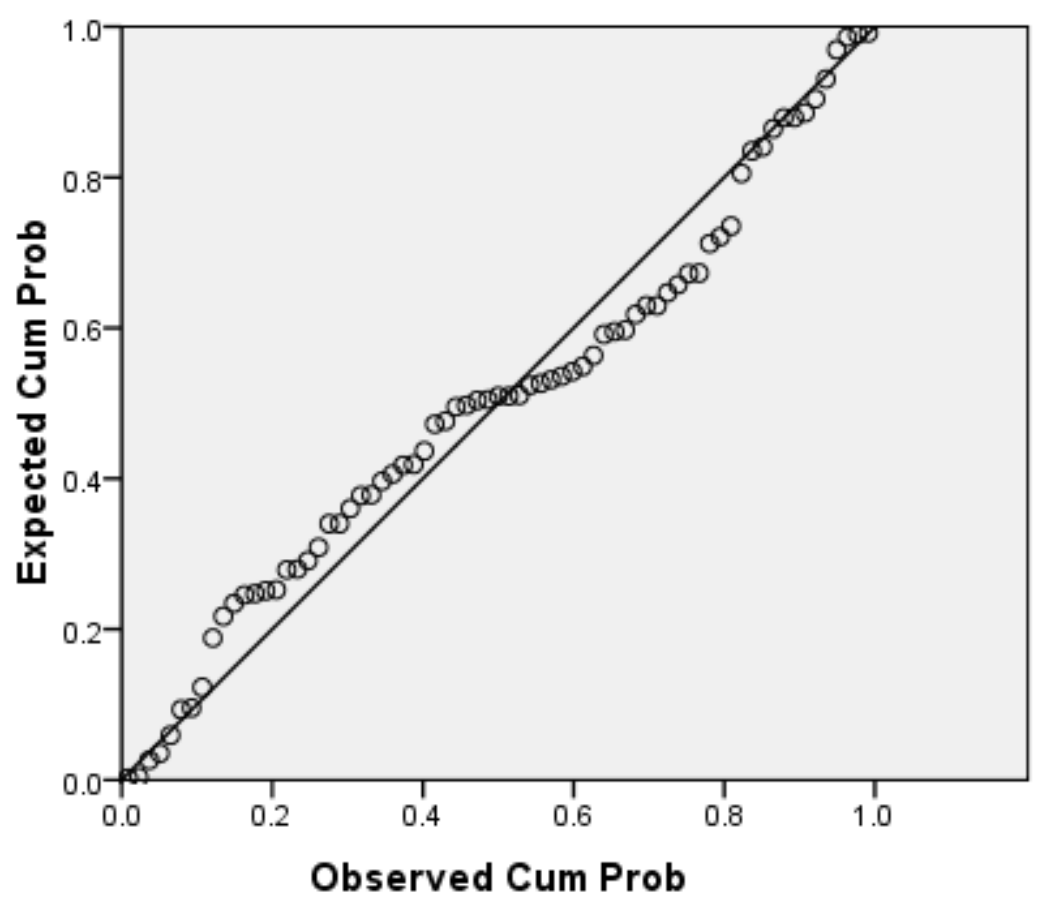

Sumber: Data Olahan SPSS 17.0 tahun 2019

Dari chart normal P-P Plot of Regression Standardized Residual terlihat bahwa data-data menyebar disekitar garis diagonal ini berarti model regresi memenuhi sasumsi normalitas.

\section{Koefisien Determinasi}

Koefisien determinasi digunakan untuk mengetahui presentasi sumbangan pengaruh variabel $\mathrm{X}$ (kecerdasan emosional) secara serentak 


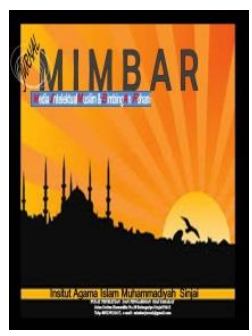

\section{MIMBAR}

Jurmal Media Intelektual Muslim dan Bimbingan Rohani

Volume 6, No. 2, 2020

ISSN (print) : 2442-3217

ISSN (online) : 2716-3806

Homepage : http://journal.iaimsinjai.ac.id/indeks.php/mimbar

terhadap variabel Y (perilaku remaja). Koefisien determinasi ini menunjukkan seberapa besar presentase variabel X (kecerdasan emosional) yang digunakan dalam penelitian ini mampu menjelaskan variasi variabel Y (perilaku remaja).

Table 6 Regresi Variabel Pengaruh Kecerdasan Emosional Terhadap Perilaku Remaja

Model Summary

\begin{tabular}{|c|c|c|c|c|c|c|c|c|c|}
\hline \multirow[b]{2}{*}{$\begin{array}{l}\text { Mod } \\
\text { el }\end{array}$} & \multirow[b]{2}{*}{$\mathrm{R}$} & \multirow[b]{2}{*}{$\begin{array}{c}\mathrm{R} \\
\text { Squar } \\
\mathrm{e}\end{array}$} & \multirow[b]{2}{*}{$\begin{array}{c}\text { Adjuste } \\
\text { d R } \\
\text { Square }\end{array}$} & \multirow{2}{*}{$\begin{array}{c}\text { Std. } \\
\text { Error of } \\
\text { the } \\
\text { Estimate }\end{array}$} & \multicolumn{5}{|c|}{ Change Statistics } \\
\hline & & & & & $\begin{array}{c}\mathrm{R} \\
\text { Square } \\
\text { Change }\end{array}$ & F Change & df1 & $\mathrm{df} 2$ & $\begin{array}{c}\text { Sig. F } \\
\text { Chang } \\
\text { e }\end{array}$ \\
\hline 1 & $.862^{\mathrm{a}}$ & .743 & .740 & 5.451 & .743 & 199.760 & 1 & 69 & .000 \\
\hline
\end{tabular}

Sumber: Data Olahan SPSS 17.0 tahun 2019

Hasil perhitungan pada tabel diatas memberikan nilai regresi atau pengaruh yang searah dan bernilai positif sebesar 0,743 . Nilai regresi 0,743 menunjukkan adanya pengaruh yang kuat antara 2 variabel. Dengan demikian dapat disimpulkan bahwa perilaku remaja sebesar dipengaruhi sebesar 74,3\% oleh kecerdasan emosional, sedangkan sisanya $(100 \%-74,3 \%=25,7)$ dijelaskan sebab-sebab yang lain. $R_{\text {square }}$ berkisar pada angka 0 sampai 1 , dengan catatan semakin kecil angka $\mathrm{R}_{\text {square, }}$ semakin lemah hubungan kedua variabel. Berikut tingkat korelasi dan kekuatan pengaruh.

\section{Analisis Regresi Linier Sederhana}

Analisis regresi linier sederhana adalah hubungan secara linier antara suatu variabel independen $(\mathrm{X})$ dengan variabel dependen (Y). Analisis ini untuk mengetahui arah hubungan variabel independen dengan variabel dependen apakah positif atau egatif dan untuk memprediksi nilai dari variabel dependen apabila nilai variabel independen mengalami kenaikan atau penurunan. 
Volume 6, No. 2, 2020

ISSN (print) : 2442-3217

ISSN (online) : 2716-3806

Homepage : http://journal.iaimsinjai.ac.id/indeks.php/mimbar

Rumus regresi linier sederhana sebagai berikut:

$\mathrm{Y}=\mathrm{a}+\mathrm{BX}$

Hasil yang diperoleh dengan menggunakan Statistical Product and Service Solutions (SPSS 17,0) terdapat pada tabel berikut ini :

Tabel 7 Regresi Linier Sederhana

Coefficients $^{\mathrm{a}}$

\begin{tabular}{|c|c|c|c|c|c|}
\hline \multirow[b]{2}{*}{ Model } & \multicolumn{2}{|c|}{$\begin{array}{c}\text { Unstandardized } \\
\text { Coefficients }\end{array}$} & \multirow{2}{*}{\begin{tabular}{|c|}
$\begin{array}{c}\text { Standardized } \\
\text { Coefficients }\end{array}$ \\
Beta \\
\end{tabular}} & \multirow[b]{2}{*}{$\mathrm{T}$} & \multirow[b]{2}{*}{ Sig. } \\
\hline & B & Std. Error & & & \\
\hline 1 (Constant) & 1.896 & 5.441 & & .348 & .729 \\
\hline $\begin{array}{l}\text { Kecerdasan } \\
\text { Emosional }\end{array}$ & .688 & .049 & .862 & 14.134 & .000 \\
\hline
\end{tabular}

a. Dependent Variable: Perilaku Remaja

Sumber: Data Olahan SPSS 17.0 tahun 2019

Persamaan regresi dari hasil perhitungan statistik didapat sebagai berikut:

$$
\begin{aligned}
& Y=a+B X \\
& Y=1,896+0,688 X
\end{aligned}
$$

Arti persamaan regresi linier tersebut di tabel adalah:

a. Konstan sebesar 1,896 menyatakan bahwa jika variabel independen tetap, maka variabel dependen sebesar 1,896.

b. Koefisien regersi sebesar $X=0,688$, menunjukkan bahwa setiap penambahan satu point pada variabel kecerdasan emosional diprediksi akan meningkat 0,688. Sebaliknya jika variabel kecerdasan emosional menurun satu point makan diprediksi akan menurun 0,688. Artinya semakin tinggi kecerdasan remaja di desa Silam maka semakin sedikit potensi remaja tersebut melakukan perilaku yang menyimpang, dan sebaliknya semakin rendah kecerdasan emosional remaja maka semakin besar pula potensi remaja tersebut melakukan perilaku yang menyimpang. 


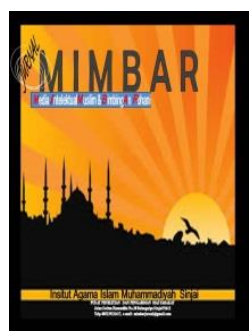

\section{MIMBAR}

Jurmal Media Intelektual Muslim dan Bimbingan Rohani

Volume 6, No. 2, 2020

ISSN (print) : 2442-3217

ISSN (online) : 2716-3806

Homepage : http://journal.iaimsinjai.ac.id/indeks.php/mimbar

\section{Analis Pengaruh Kecerdasan Emosional terhadap Perilaku Remaja}

Dalam penelitian ini, untuk mengetahui atau membuktikan adanya pengaruh kecerdasan emosional terhadap perilaku remaja maka penulis menggunakan regresi sederhana dengan menggunakan SPSS 17,0. Setelah diketahui besarnya hubungan antara variabel $\mathrm{X}$ dan $\mathrm{Y}$, maka penulis akan menginterpretasikan nilai tersebut pada tabel berikut untuk mengetahui seberapa besar pengaruhnya.

Tabel 8 Tingkat Korelasi dan Kekuatan Pengaruh ${ }^{14}$

\begin{tabular}{|c|c|}
\hline Nilai r & Interpretasi \\
\hline $0,80-1,00$ & Pengaruh Sangat Kuat \\
\hline $0,60-0,79$ & Pengaruh Kuat \\
\hline $0,40-0,59$ & Pengaruh Cukup \\
\hline $0,20-0,39$ & Pengaruh Lemah \\
\hline $0,00-0,19$ & Pengaruh Sangat Lemah \\
\hline
\end{tabular}

Penulis menggunakan analisis regrsi linier dengan menggunakan SPSS 17,0 untuk melihat adanya hubungan antara lingkungan kecerdasan emosional dan perilaku remaja.

Tabel 9 Korelasi Kecerdasan Emosional dan Perilaku Remaja Correlations

\begin{tabular}{|ll|r|r|}
\hline & \multicolumn{1}{|c|}{$\begin{array}{c}\text { Perilaku } \\
\text { Remaja }\end{array}$} & $\begin{array}{c}\text { Kecerdasan } \\
\text { Emosional }\end{array}$ \\
\hline Pearson Correlation & Perilaku Remaja & 1.000 & .862 \\
& $\begin{array}{l}\text { Kecerdasan } \\
\text { Emosional }\end{array}$ & .862 & 1.000 \\
\hline Sig. (1-tailed) & Perilaku Remaja & .000 & .000 \\
& Kecerdasan & & \\
& Emosional & & \\
\hline
\end{tabular}

\footnotetext{
${ }^{14}$ Iskandar, MetodePenelitian Kuanttitatif dan Kualitatif, (Jakarta: GP Press, 2009), hal. 127.
} 
Volume 6, No. 2, 2020

ISSN (print) : 2442-3217

ISSN (online) : 2716-3806

Homepage : http://journal.iaimsinjai.ac.id/indeks.php/mimbar

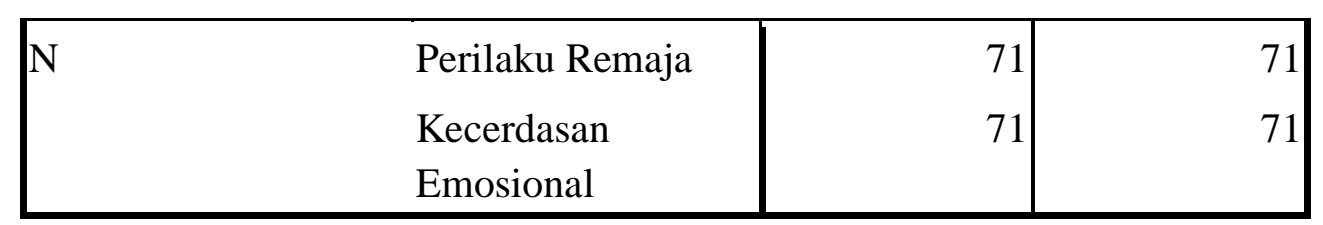

Sumber: Data Olahan SPSS 17.0 tahun 2019

Dari hasil olahan diatas disebutkan bahwa hasil Correlations variabel $\mathrm{X}$ dan $\mathrm{Y}$ sebesar 0,862, artinya terdapat hubungan yang signifikan antara variabel kecerdasan emosional $(\mathrm{X})$ dan variabel perilaku remaja (Y). Dapat disimpulkan bahwa kecerdasan emosional berpengaruh sangat kuat pada perilaku remaja di desa Silam kecamatan Kuok kabupaten Kampar.

\section{Uji Hipotesis}

Hipotesis yang dipakai pada penelitian ini adalah hipotesis statistik atau untuk menguji kebenaran apakah ada pengaruh kecerdasan emosional terhadap perilaku remaja. Hipotesis penelitian memakai lambang $\mathrm{H}_{\mathrm{a}}$ untuk pernyataan bahwa ada pengaruh variabel kecerdasan emosional terhadap perilaku remaja. Sedangkan untuk alternatif lambangnya $\mathrm{H}_{\mathrm{o}}$ yaitu tidak ada pengaruh kecerdasan emosional terhadap perilaku remaja atau $\mathrm{H}_{\mathrm{a}}$ bertentangan dengan $\mathrm{H}_{\mathrm{o}} \cdot{ }^{15}$ Pengujian hipotesis dilakukan dengan analisis regresi. Berikut hipotesis yang diajukan dalam bentuk kalimat.

$\mathrm{H}_{\mathrm{a}}$ : Ada pengaruh yang signifikan secara parsial kecerdasan emosional terhadap perilaku remaja di desa Silam kecamatan Kuok kabupaten Kampar.

$\mathrm{H}_{\mathrm{o}}$ : Tidak ada pengaruh yang signifikan secara parsial kecerdasan emosional terhadap perilaku remaja di desa Silam kecamatan Kuok kabupaten Kampar.

\footnotetext{
${ }^{15}$ Riduwan, dkk, Op. Cit., hal. 103.
} 
Volume 6, No. 2, 2020

ISSN (print) : 2442-3217

ISSN (online) : 2716-3806

Homepage : http://journal.iaimsinjai.ac.id/indeks.php/mimbar

\section{Coefficients}

\section{Coefficients $^{\mathrm{a}}$}

\begin{tabular}{|c|c|c|c|c|c|}
\hline \multirow[b]{2}{*}{ Model } & \multicolumn{2}{|c|}{$\begin{array}{l}\text { Unstandardized } \\
\text { Coefficients }\end{array}$} & \multirow{2}{*}{$\begin{array}{c}\text { Standardize } \\
\mathrm{d} \\
\text { Coefficients } \\
\\
\text { Beta }\end{array}$} & \multirow[b]{2}{*}{$\mathrm{T}$} & \multirow[b]{2}{*}{ Sig. } \\
\hline & B & $\begin{array}{l}\text { Std. } \\
\text { Error }\end{array}$ & & & \\
\hline $\begin{array}{l}\text { (Constant) } \\
\text { Kecerdasan } \\
\text { Emosional }\end{array}$ & $\begin{array}{r}1.896 \\
.688\end{array}$ & $\begin{array}{r}5.441 \\
.049\end{array}$ & .862 & $\begin{array}{r}.348 \\
14.134\end{array}$ & $\begin{array}{l}.729 \\
.000\end{array}$ \\
\hline
\end{tabular}

Sumber: Data Olahan SPSS 17.0 tahun 2019

a. Uji Hipotesis berdasarkan uji $\mathrm{t}$

Uji hipotesis berdasarkan uji t menggunakan regresi sederhana dengan mengetahui nilai $t_{\text {hitung }}$ pada tabel coefficients dan mengetahui $\mathrm{t}_{\text {tabel }}$ dengan tingkat signifikan $(\alpha=0,05)$, df atau $\mathrm{dk}$ (derajat kebebasan $)=\mathrm{N}-2$.

Kaidah keputusan

Jika nilai $\mathrm{t}$ hitung $\geq \mathrm{t}$ tabel, maka Ho ditolak dan Ha diterima, artinya signifikan

Jika nilai $\mathrm{t}_{\text {hitung }} \leq \mathrm{t}_{\text {tabel, }}$, maka Ho diterima dan Ha ditolak, artinya tidak signifikan.

Diketahui:

Tingkat signifikan adalah 0,05 untuk uji 2 pihak

Dk $($ derajat kebebasan $)=\mathrm{N}-2$ atau $71-2=69$

$\mathrm{T}_{\text {tabel }}$ dari $69=1,994$

$\mathrm{T}_{\text {hitung }}=14,134$ 
Dari hasil pengolahan menunjukkan bahwa $\mathrm{t}_{\text {hitung }}>\mathrm{t}$ tabel, atau 14,134 > 1,994, maka Ho ditolak dan Ha diterima, artinya signifikan. Jadi, kecerdasan emosional berpengaruh signifikan terhadap perilaku remaja.

b. Uji Hipotesis menggunakan uji probabilitas

Kaidah keputusan:

Jika nilai probabilitas $\alpha(0,05) \leq$ nilai probabilitas Sig, maka Ho diterima dan Ha ditolak, artinya tidak signifikan.

Jika nilai probabilitas $\alpha(0,05) \geq$ nilai probabilitas Sig, maka Ho ditolak dan Ha dierima, artinya signifikan.

Pada tabel coefficients diperoleh variabel kecerdasan emosional dan perilaku remaja nilai probabilitas Sig. Sebesar 0,00, kemudian jika dibandingkan dengan probabilitas 0,05 , ternyata nilai probabilitas 0,05 lebih besar dari nilai probabilitas Sig atau $(0,05>0,00)$, maka Ho ditolak dan Ha diterima artinya sidnifikan. Terbukti bahwa kecerdasan emosional berpengaruh signifikan terhadap perilaku remaja.

\section{Simpulan}

Setelah menganalisis dan membahas pengaruh kecerdasan emosional terhadap perilaku remaja di desa Silam kecamatan Kuok kabupaten Kampar maka penulis dapat menarik kesimpulan sebagai berikut:

1. Dari hasil Koefisien Determinasi menunjukkan nilai regresi atau pengaruh yang searah dan bernilai positif sebesar 0,743. Nilai regresi 0,743 menunjukkan adanya pengaruh yang kuat antara 2 variabel. Dengan demikian dapat disimpulkan bahwa perilaku remaja sebesar dipengaruhi sebesar 74,3\% oleh kecerdasan emosional, sedangkan sisanya $(100 \%-74,3 \%=25,7)$ dijelaskan sebab-sebab yang lain. 


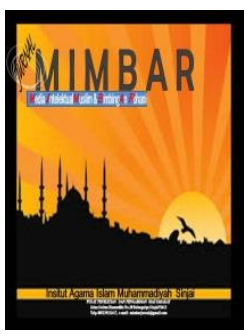

\section{MIMBAR}

Jurmal Media Intelektual Muslim dan Bimbingan Rohani

Volume 6, No. 2, 2020

ISSN (print) : 2442-3217

ISSN (online) : 2716-3806

Homepage : http://journal.iaimsinjai.ac.id/indeks.php/mimbar

2. Dari hasil korelasi antara kecerdasan emosional dan perilaku remaja diperoleh hasil koefisien 0,862 yang berada pada interval 0,80 - 1,00 dengan tingkat hubungan sangat kuat antara variabel $\mathrm{X}$ dan $\mathrm{Y}$.

3. Dari hasil regresi linier sederana didapat hasil Koefisien regersi sebesar $\mathrm{X}=0,688$, menunjukkan bahwa setiap penambahan satu point pada variabel kecerdasan emosional diprediksi akan meningkat 0,688. Artinya semakin tinggi kecerdasan remaja di desa Silam maka semakin sedikit potensi remaja tersebut melakukan perilaku yang menyimpang, dan sebaliknya semakin rendah kecerdasan emosional remaja maka semakin besar pula potensi remaja tersebut melakukan perilaku yang menyimpang.

4. Dari hasil Coefficient pada uji hipotesis menunjukkan bahwa $t_{\text {hitung }}>t_{\text {tabel }}$, atau 14,134 > 1,994, maka Ho ditolak dan Ha diterima, artinya signifikan. Jadi, kecerdasan emosional berpengaruh signifikan terhadap perilaku remaja 


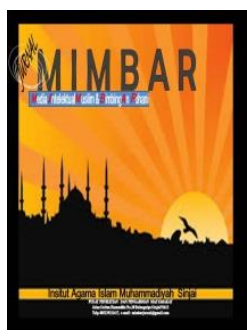

\section{MIMBAR}

Jurmal Media Intelektual Muslim dan Bimbingan Rohani

Volume 6, No. 2, 2020

ISSN (print) : 2442-3217

ISSN (online) : 2716-3806

Homepage : http://journal.iaimsinjai.ac.id/indeks.php/mimbar

\section{REFERENSI}

Hurlock, E.,(2006), Psikologi Perkembangan.Jakarta: Erlangga.

Iskandar, (2009), Metode Penulisan Kuantitatif dan Kualitatif, Jakarta: GP Press.

Riduwan, dkk, (2013), Cara Mudah Belajar SPSS 17.0 dan Aplikasi Statistik Penulisan, Bandung: Alfabeta.

Sadiah, Dewi, (2015), Metode Penulisan Dakwah, Pendekatan Kualitatif dan Kuantitatif. Bandung: Remaja Rosdakarya.

Sarwono, Sarlito Wirawan, (2016), Psikologi Remaja, Jakarta: Rajawali Pers.

Sugiyono, (2009), Statistik untuk Penulisan, Bandung: Alfabeta. ,(2013), Metode Penulisan Kuantitatif, Kualitatif dan $R \& D$, Bandung: Alfabeta.

Upton, Penney, (2012), Psikologi Perkembangan. Jakarta: Erlangga.

Willis, Sofyan, Remaja dan Masalahnya; Mengupas Berbagai Bentuk Kenakalan Remaja Narkoba Free Sex dan Pemecahannya, Bandung: Alfabeta.

Yulianti, Alma, (2013), Psikologi Perkembangan, Sepanjang Rentang Kehidupan, Pekanbaru: Al-Mujtahadah Press.

Yusuf, Syamsu.(2010), Psikologi Perkembangan, Anak dan Remaja.Bandung: Rosda Karya.

Kontak Pengelola

Siar Nim'ah, M.Ag

Asriadi, S.Pd., M.Sos

Insitut Agama Islam Muhammadiyah Sinjai

Telepon 085247843790 / almubarakj1@gmail.com

mimbarjurnal@gmail.com 